\title{
New Heteroleptic Ru II/Diphosphine Complexes with Cytotoxicity against Human Breast and Murine Ascitic Sarcoma 180 Tumor Cells
}

\author{
Benedicto A. V. Lima, ${ }^{a}$ Rodrigo S. Corrêa, ${ }^{(*, b}$ Angélica E. Graminha, ${ }^{c}$ \\ Jaldyr J. G. Varela Júnior, ${ }^{d}$ Albérico B. F. da Silva, ${ }^{e}$ Javier Ellena, ${ }^{e}$ Thales E. M. Silva ${ }^{f}$ \\ and Alzir A. Batista ${ }^{\circledR}, c$ \\ ${ }^{a}$ Universidade Federal do Maranhão, 65940-000 Grajaú-MA, Brazil \\ ${ }^{b}$ Departamento de Química, Universidade Federal de Ouro Preto, \\ 35400-000 Ouro Preto-MG, Brazil \\ ${ }^{c}$ Departamento de Química, Universidade Federal de São Carlos, CP 676, \\ 13565-905 São Carlos-SP, Brazil \\ ${ }^{d}$ Colégio Universitário, Universidade Federal do Maranhão, 65080-805 São Luís-MA, Brazil \\ ${ }^{e}$ Instituto de Física de São Carlos, Universidade de São Paulo, 13560-970 São Carlos-SP, Brazil \\ ${ }^{f}$ Universidade Federal de Alfenas, 37715-400 Poços de Caldas-MG, Brazil
}

\begin{abstract}
The preparation, characterization, theoretical calculations and biological application of four $\mathrm{Ru}^{\mathrm{II}}$ complexes with 2-picolinate (pic), 2,2'-bipyridine (bipy) and $\mathrm{P}-\mathrm{P}$ as ligands $[\mathrm{P}-\mathrm{P}=1$,1-bis(diphenylphosphino)methane (dppm-1), 1,2-bis(diphenylphosphino)ethane (dppe-2), 1,3-bis(diphenylphosphino)propane (dppp-3) or 1,1'-bis(diphenylphosphino)ferrocene (dppf-4)], is here presented. The complexes $\mathbf{1 - 4}$, with general formula $[\mathrm{Ru}(\mathrm{pic})(\mathrm{P}-\mathrm{P})(\mathrm{bipy})] \mathrm{PF}_{6}$, were characterized by elemental analysis and by infrared (IR), UV-Vis, nuclear magnetic resonance (NMR ${ }^{1} \mathrm{H}$ and ${ }^{13} \mathrm{P}\left\{{ }^{1} \mathrm{H}\right\}$ ) spectroscopies, cyclic voltammetry and X-ray crystallography technique. Additionally, preliminary in vitro tests against human breast (MDA-MB-231) and murine ascitic sarcoma 180 (S180) tumor cell lines were carried out, and compared with cisplatin, a reference drug. The drug concentration at which $50 \%$ of the cells are viable relative to the control $\left(\mathrm{IC}_{50}\right)$ values found for complexes 1, 2, 3 and $\mathbf{4}$ against MDA-MB-231 tumor cells were around 14.6, 7.6, 3.3 and $0.4 \mu \mathrm{M}$, respectively, while against $\mathrm{S} 180$ tumor cells these complexes showed $\mathrm{IC}_{50}$ values of $71.9,31.3,11.2$ and $3.5 \mu \mathrm{M}$, respectively. Therefore, the complexes were more active against MDA-MB-231 than S180.
\end{abstract}

Keywords: ruthenium(II), picolinate, biphosphines, murine ascitic sarcoma 180, human breast cancer

\section{Introduction}

Metal based therapeutics are a precious class of drugs in cancer treatment, and ruthenium-based complexes are promising alternative candidates to antineoplastic therapeutics, because this class of compounds have shown selective bioactivity and the good ability to overcome the resistance that platinum-based therapeutics face. ${ }^{1,2}$ Another advantage to use ruthenium complexes as drug is that in some cases it has been shown these kind of compounds containing organic drugs, such as ligands, can overcome

*e-mail: rodrigocorrea@ufop.edu.br; daab@ufscar.br resistance developed by bacteria to the organic compounds alone. $^{3}$

Recently, a great number of ruthenium complexes containing different ligands, have been tested as antitumor agents against different kinds of tumor cell lines, showing to be very active..$^{4-9}$ Thus, picolinate containing complex $\left[\mathrm{Ru}\left(\eta^{6}-p\right.\right.$-cymene $) \mathrm{Cl}$ (picolinate) $]$ is active against $\mathrm{HeLa}$ (drug concentration at which $50 \%$ of the cells are viable relative to the control $\left.\left(\mathrm{IC}_{50}\right)=82.0 \mu \mathrm{M}\right)$ and human melanoma cells $\left(\mathrm{FemX}, \mathrm{IC}_{50}=36.2 \mu \mathrm{M}\right) \cdot{ }^{10}$ The possible reason for this behavior is that the $\left[\mathrm{Ru}\left(\eta^{6}-p\right.\right.$-cymene $)$ $\mathrm{Cl}$ (picolinate)] accumulates in the deoxyribonucleic acid (DNA) molecule, since it has high affinity for DNA-binding. 
According to Gligorijević et al., ${ }^{11}$ a possible reason for this is the obstruction of complex/DNA interactions. The rotation of the ligand around the $\mathrm{Ru}-\mathrm{N}$ bond in complexes $\left[\mathrm{Ru}\left(\eta^{6}-p\right.\right.$-cymene $\left.)(\mathrm{L}) \mathrm{Cl}_{2}\right]$, (L: 3-acetylpyridine, 2-amino-5-chloropyridine) and the presence of $-\mathrm{COOH}$ in [Ru( $\eta^{6}$-p-cymene)(HL)Cl], (HL: 2,3-pyridinedicarboxylic acid, 2,4-pyridinedicarboxylic acid) can impair the complex intercalation through the $\eta^{6}$-arene group. ${ }^{11}$

In particular, phosphine ligands can form complexes with various d-block metals ( $\mathrm{Au}, \mathrm{Ag}, \mathrm{Cu}, \mathrm{Ru}, \mathrm{Pd}, \mathrm{Pt})$ and some of these compounds have been evaluated as potential antitumor agents against human tumor cell lines. ${ }^{12-17}$ In addition, the coordination of picolinate ligand together with some phosphines, in metal complexes, might enhance their biological activity. ${ }^{18,19}$

Preliminary results obtained by our research group for ruthenium(II) complexes containing 2,2'-bipyridine (bipy) and its derivatives, as well as diphosphines as ligands, are very promising as anticancer agents. ${ }^{20-22}$ These results have encouraged us to explore these kinds of systems, not only because of the good results obtained, but also because it is possible to investigate the relationship between the structural parameter of the complexes and their biological activity. Recently, we have observed that the substitution of chlorido ligands from the cis- $\left[\mathrm{RuCl}_{2}(\mathrm{dppe})_{2}\right]$ (dppe: 1,2-bis(diphenylphosphino)ethane) complex by a propionate ligand, forming the $\left[\mathrm{Ru}\left(\eta^{2}-\mathrm{O}_{2} \mathrm{CCH}_{2} \mathrm{CH}_{3}\right)(\mathrm{dppe})_{2}\right] \mathrm{PF}_{6}$ complex, increased the cytotoxicity against a series of tumor cells (GM07492A, HepG2, MCF-7, MO59 J, S180), when compared with the starting precursor. The better solubility of the propionate complex probably leads to higher availability in the culture medium, when compared with the precursor complex. The $\left[\mathrm{Ru}\left(\eta^{2}-\mathrm{O}_{2} \mathrm{CCH}_{2} \mathrm{CH}_{3}\right)(\mathrm{dppe})_{2}\right] \mathrm{PF}_{6}$ complex $\left(\mathrm{IC}_{50}=0.18 \pm 0.03 \mu \mathrm{M}\right)$ shows to be substantially more active than cisplatin $(64.8 \pm 0.2 \mu \mathrm{M}),{ }^{23}$ especially against murine ascistic sarcoma 180 cells.

Additionally, $\mathrm{Ru}^{\mathrm{II}}$ complexes containing only one diphosphine ligand also present good antitumor activity. As example, the complexes of the type $[\mathrm{Ru}(\mathrm{AA})(\mathrm{dppb})(\mathrm{bipy})] \mathrm{PF}_{6}$ ( $\mathrm{dppb}=1,4$-bis(diphenylphosphino)butane, $\mathrm{AA}=$ leucine, alanine, methionine, glycine, aspartic acid), which were tested against S180 sarcoma, showed antitumor activity, with $\mathrm{IC}_{50}$ ranging from 22.53 to $50.18 \mu \mathrm{M} .^{24}$ In this way, as part of our ongoing efforts to improve and understand the biological activity of ruthenium complexes, here we present the synthesis, characterization, $\mathrm{X}$-ray crystallographic structures and theoretical study of four ruthenium complexes containing picolinate and bipyridine ligands, as common ligands in all complexes, and the diphosphines: bis(diphenylphosphino)methane (dppm-1), 1,2-bis(diphenylphosphino)ethane (dppe-2), 1,3-bis(diphenylphosphino)propane (dppp-3) and 1,1'-bis(diphenylphosphino)ferrocene (dppf-4). The main aim of this report is to evaluate the influence of the diphosphine on the cytotoxicity of the complexes against MDA-MB231 and S180 tumor cell lines.

\section{Experimental}

The experimental procedure used in this work was previously described. ${ }^{25-29}$ The analysis of the molecular orbital (MO) compositions in terms of fragment MO's (Frontier Orbital-FO) were performed using AOMix-CDA..$^{30}$ The molecular orbitals were visualized using Chemissian software. ${ }^{31}$

\section{Partition coefficient $(\mathrm{P})$}

Water- $n$-octanol partition coefficients were determined using the stir flask method, as previously described. ${ }^{8}$

\section{In vitro cytotoxicity}

In vitro cytotoxicity assays on cultured human tumor cell lines still represent the standard method for the initial screening of potential antitumoral agents. Thus, as a first step in assessing their pharmacological properties, the new ruthenium complexes were assayed against human breast tumor cell lines MDA-MB-231 and murine ascistic sarcoma 180 tumor cells (S180) (ATCC TIB-66). The cells were routinely maintained in Dulbecco's modified Eagle's medium (DMEM) supplemented with $10 \%$ fetal bovine serum (FBS), at $37^{\circ} \mathrm{C}$ in a humidified $5 \% \mathrm{CO}_{2}$ atmosphere. After reaching confluence, the cells were detached by trypsinization and counted. For the cytotoxicity assay, $5 \times 10^{4}$ cells well $^{-1}$ were seeded in $200 \mu \mathrm{L}$ of complete medium in 96-well assay microplates (Corning Costar). The plates were incubated at $37^{\circ} \mathrm{C}$ in $5 \% \mathrm{CO}_{2}$ for $24 \mathrm{~h}$ to allow cell adhesion, prior to drug testing. All tested compounds were dissolved in sterile dimethyl sulfoxide (DMSO, stock solution with maximum concentration of $20 \mathrm{mmol} \mathrm{L}^{-1}$ ) and diluted to 5.0, 2.0, 1.0, 0.5, 0.2, 0.02 and $0.002 \mathrm{mmol} \mathrm{L}^{-1}$. From each of these dilute samples, $2 \mu \mathrm{L}$ aliquots were added to $200 \mu \mathrm{L}$ medium (without FBS) giving a final concentration of DMSO of approximately $1 \%$ and a final concentration of the complex diluted about 100 times. Attached cells were exposed to the compounds for a $24 \mathrm{~h}$ period. Cell respiration, as an indicator of cell viability, was then determined by the mitochondrial-dependent reduction of 3-(4,5-dimethylthiazol-2-yl)-2,5-diphenyltetrazolium bromide (MTT) to formazan. ${ }^{32}$ MTT solution $\left(0.5 \mathrm{mg} \mathrm{mL}^{-1}\right)$ was added to cell cultures and incubated for $3 \mathrm{~h}$, after 
which $100 \mathrm{~mL}$ of isopropanol was added to dissolve the precipitated formazan crystals. The conversion of MTT to formazan by metabolically viable cells was monitored in an automated microplate reader at $570 \mathrm{~nm}$. The cell viability percentage was calculated by dividing the average absorbance of the cells treated with the test compounds by that of the control; cell viability percentage was plotted against drug concentration (logarithmic scale) to determine the drug concentration at which $50 \%$ of the cells are viable relative to the control $\left(\mathrm{IC}_{50}\right)$, the error being estimated for the average of 3 trials.

\section{Synthetic procedures}

All chemicals used were of analytical grade. The reagents, with high purity, were from Sigma-Aldrich Inc., (St. Louis, USA). First, $0.15 \mathrm{mmol}$ of $\mathrm{Et}_{3} \mathrm{~N}$ was added to a degassed solution of $0.10 \mathrm{mmol}$ of $c i s-\left[\mathrm{RuCl}_{2}(\mathrm{P}-\mathrm{P})(\mathrm{bipy})\right]$ (P-P = dppm, dppe, dppp ${ }^{33}$ or dppf) ${ }^{34}$ in $30 \mathrm{~mL}$ of $\mathrm{CH}_{2} \mathrm{Cl}_{2}$ $0.12 \mathrm{mmol}$ of picH. The mixture was allowed to react for $24 \mathrm{~h}$ under argon then $0.15 \mathrm{mmol}$ of $\mathrm{NH}_{4} \mathrm{PF}_{6}$ was added in order to replace the chloride counter-ion, by the $\mathrm{PF}_{6}^{-}$. After one hour of reaction, the volume of the mixture was reduced to ca. $2 \mathrm{~mL}$ and the complexes were precipitated by addition of $15 \mathrm{~mL}$ of diethyl ether. The precipitate was filtered off, washed with water $(2 \times 10 \mathrm{~mL})$ and diethyl ether $(2 \times 10 \mathrm{~mL})$. Yield: $85-95 \%$.

\section{[Ru(pic)(dppm)(bipy)]PF ${ }_{6}(\mathbf{1})$}

NMR ${ }^{1} \mathrm{H}\left(400 \mathrm{MHz},\left(\mathrm{CD}_{3}\right)_{2} \mathrm{CO}\right) \delta 9.00(\mathrm{~m}, 1 \mathrm{H}$, bipy $)$, 8.47 (d, $1 \mathrm{H}, J 8.4 \mathrm{~Hz}$, bipy), 8.38 (d, $1 \mathrm{H}, J 5.6 \mathrm{~Hz}$, bipy), 8.35 (d, $1 \mathrm{H}, J 8.4 \mathrm{~Hz}$, bipy), 8.14 (dt, $1 \mathrm{H}, J 5.6$ and $1.6 \mathrm{~Hz}$, bipy), 8.08-8.04 (m, 2H, Ph), 8.02-7.91 (1H, pic; 2H, phenyl $(\mathrm{Ph})$; $\mathrm{m}, 1 \mathrm{H}$, bipy), 7.78 (t, $1 \mathrm{H}, J 6.4 \mathrm{~Hz}$, pic), 7.68-7.51 (1H, pic; $\mathrm{m}, 6 \mathrm{H}, \mathrm{Ph}), 7.50-7.45(\mathrm{~m}, 2 \mathrm{H}, \mathrm{Ph}), 7.29(\mathrm{t}, 1 \mathrm{H}, J 7.2 \mathrm{~Hz}$, bipy), 7.22 (d, 1H, J 7.2 Hz, bipy), 7.19-6.99 (1H, pic; m, $6 \mathrm{H}, \mathrm{Ph}), 6.81-6.74(\mathrm{~m}, 2 \mathrm{H}, \mathrm{Ph}), 5.40-5.28\left(\mathrm{~m}, 1 \mathrm{H}, \mathrm{CH}_{2}\right)$, 5.01-4.90 (m, $\left.1 \mathrm{H}, \mathrm{CH}_{2}\right)$; anal. calcd. for $\mathrm{C}_{41} \mathrm{H}_{34} \mathrm{~N}_{3} \mathrm{O}_{2} \mathrm{P}_{3} \mathrm{~F}_{6} \mathrm{Ru}$ : exptl./calcd.: C, 54.29/54.19; H, 3.68/3.77; N, 4.71/4.62.

\section{[Ru(pic)(dppe)(bipy)]PF $F_{6}(2)$}

NMR ${ }^{1} \mathrm{H}\left(400 \mathrm{MHz},\left(\mathrm{CD}_{3}\right)_{2} \mathrm{CO}\right) \delta 8.95(\mathrm{~m}, 1 \mathrm{H}$, bipy $)$, 8.34 (d, 1H, $J 8.0 \mathrm{~Hz}$, bipy), 8.17 (d, 1H, $J$ 5.6, bipy), 8.16-8.08 (4H, m, Ph), 8.02 (dt, $1 \mathrm{H}, J 7.6$ and $1.2 \mathrm{~Hz}$, pic), 7.98-7.94 (m, 1H, bipy), 7.83 (dt, 1H, J 7.6 and $1.2 \mathrm{~Hz}$, pic), 7.72 (t, 1H, J 4.8 Hz, bipy), 7.60-7.50 (1H, bipy; m, 4H, Ph), 7.50-7.41 (m, 5H, Ph), 7.34-7.28 (m, 1H, bipy), 7.26-7.17 (1H, pic; m, 3H, Ph), $7.13(\mathrm{dt}, 1 \mathrm{H}$, $J 6.4$ and $1.2 \mathrm{~Hz}$, pic), 7.08 (m, 1H, bipy), 6.89 (dt, $2 \mathrm{H}$, $J 7.6$ and $2.4 \mathrm{~Hz}, \mathrm{Ph}$ ), 6.43 (t, 2H, J 7.2 Hz, Ph), 3.32-2.90 $\left(\mathrm{m}, 2 \mathrm{H}, \mathrm{CH}_{2}\right), 2.50-2.34\left(\mathrm{~m}, 1 \mathrm{H}, \mathrm{CH}_{2}\right), 2.13-1.98(\mathrm{~m}, 1 \mathrm{H}$,
$\mathrm{CH}_{2}$ ); anal. calcd. for $\mathrm{C}_{42} \mathrm{H}_{36} \mathrm{~N}_{3} \mathrm{O}_{2} \mathrm{P}_{3} \mathrm{~F}_{6} \mathrm{Ru}$ : exptl./calcd.: C, 54.48/54.67; H, 3.79/3.93; N, 4.77/4.55.

$[\mathrm{Ru}($ pic) (dppp)(bipy)]PF 6 (3)

NMR ${ }^{1} \mathrm{H}\left(400 \mathrm{MHz},\left(\mathrm{CD}_{3}\right)_{2} \mathrm{CO}\right) \delta 9.43(\mathrm{~d}, 1 \mathrm{H}, J 5.6 \mathrm{~Hz}$, bipy), 8.66 (m, 1H, bipy), 8.38 (dd, $1 \mathrm{H}, J 8.4$ and $1.2 \mathrm{~Hz}$, bipy), 8.22 (dt, $1 \mathrm{H}, J 8.4$ and $1.2 \mathrm{~Hz}$, bipy), $8.06(\mathrm{~d}, 1 \mathrm{H}$, $J 8.4 \mathrm{~Hz}$, bipy), $8.02(\mathrm{~m}, 2 \mathrm{H}, \mathrm{Ph}), 7.88-7.78(1 \mathrm{H}$, pic; $\mathrm{m}$, $2 \mathrm{H}, \mathrm{Ph}), 7.75(\mathrm{dt}, 1 \mathrm{H}, J 7.6$ and $1.6 \mathrm{~Hz}, \mathrm{pic}), 7.57-7.42$ (m, 6H, Ph), 7.33-7.28 (m, 1H, bipy), 7.27-7.17 (1H, pic; $\mathrm{m}, 1 \mathrm{H}$, bipy), 7.10-7.04 (m, 6H, Ph), 6.98-6.90 (1H, pic; $\mathrm{m}, 2 \mathrm{H}, \mathrm{Ph}), 6.77$ (m, 1H, bipy), 6.38 (t, 2H, J $8.0 \mathrm{~Hz}, \mathrm{Ph}$ ), 3.20-3.02 (m, $\left.2 \mathrm{H}, \mathrm{CH}_{2}\right), 2.79-2.62\left(\mathrm{~m}, 2 \mathrm{H}, \mathrm{CH}_{2}\right), 2.40-$ $2.20\left(\mathrm{~m}, 1 \mathrm{H}, \mathrm{CH}_{2}\right), 2.03-1.87\left(\mathrm{~m}, 1 \mathrm{H}, \mathrm{CH}_{2}\right)$; anal. calcd. for $\mathrm{C}_{43} \mathrm{H}_{38} \mathrm{~N}_{3} \mathrm{O}_{2} \mathrm{P}_{3} \mathrm{~F}_{6} \mathrm{Ru}$ : exptl/calcd.: C, 53.79/54.09; $\mathrm{H}$, 4.43/4.22; N, 4.66/4.40.

$[\mathrm{Ru}($ pic) (dppf)(bipy)]PF 6 (4)

NMR ${ }^{1} \mathrm{H}\left(400 \mathrm{MHz},\left(\mathrm{CD}_{3}\right)_{2} \mathrm{CO}\right) \delta 8.89(\mathrm{~d}, 1 \mathrm{H}, J 5.6 \mathrm{~Hz}$, bipy), 8.05-7.98 (m, 2H, bipy), 7.96 (d, 1H, J $8.0 \mathrm{~Hz}$, bipy), 7.91 (dt, $1 \mathrm{H}, J 7.6$ and $1.2 \mathrm{~Hz}$, pic), $7.70(\mathrm{dt}, 1 \mathrm{H}$, $J 8.0$ and $1.2 \mathrm{~Hz}$, bipy), 7.67-7.61 (m, 2H, Ph), 7.60-7.50 $(1 \mathrm{H}$, pic; $1 \mathrm{H}$, bipy; $\mathrm{m}, 3 \mathrm{H}, \mathrm{Ph}), 7.39 \mathrm{dt}, 2 \mathrm{H}, J 7.6$ and $1.6 \mathrm{~Hz}, \mathrm{Ph}), 7.35-7.31$ (m, 1H, bipy), 7.28-7.20 (m, 4H, $\mathrm{Ph}), 7.18-7.11(1 \mathrm{H}$, pic; $\mathrm{m}, 2 \mathrm{H}, \mathrm{Ph}), 7.05-6.93(1 \mathrm{H}$, pic; 1H, bipy; m, 5H, Ph), 6.56 (t, 2H, J 6.8 Hz, Ph), 5.24 (m, $1 \mathrm{H}$, cyclopentadienyl $(\mathrm{Cp})), 4.79(\mathrm{~m}, 1 \mathrm{H}, \mathrm{Cp}), 4.61(\mathrm{~m}, 1 \mathrm{H}$, Cp), 4.45 (m, 2H, Cp), 4.42 (m, 1H, Cp), 4.36 (m, 1H, Cp), $4.16\left(\mathrm{~m}, 1 \mathrm{H}, \mathrm{Cp}\right.$ ); anal. calcd. for $\mathrm{C}_{50} \mathrm{H}_{40} \mathrm{~N}_{3} \mathrm{O}_{2} \mathrm{P}_{3} \mathrm{~F}_{6} \mathrm{FeRu}$ : exptl./calcd.: C, 54.10/54.31; H, 3.66/3.73; N, 4.06/3.79.

\section{Results and Discussion}

\section{Synthesis and characterization}

Complexes 1-4 were obtained from the precursors cis$\left[\mathrm{RuCl}_{2}(\mathrm{P}-\mathrm{P})(\right.$ bipy)$\left.)\right][\mathrm{P}-\mathrm{P}=1,1$-bis(diphenylphosphino) methane (dppm, 1), 1,2-bis(diphenylphosphino) ethane (dppe, 2), 1,3-bis(diphenylphosphino)propane (dppp, 3) or 1,1'-bis(diphenylphhosphine)ferrocene (dppf, 4)] by two chlorido ligands exchanged to one picolinate ion (see Scheme 1). The molar conductivity measurements for the ruthenium complexes (1-4), in dichloromethane, present values consistent with 1:1 electrolytes (17.1-36.2 S cm$\left.{ }^{2} \mathrm{~mol}^{-1}\right)$, in which one $\mathrm{PF}_{6}^{-}$ anion is present as counter-ion. ${ }^{31} \mathrm{P}\left\{{ }^{1} \mathrm{H}\right\}$ NMR spectra of the compounds $\mathbf{1 - 4}, 161.98 \mathrm{MHz}, \mathrm{CH}_{2} \mathrm{Cl}_{2} / \mathrm{D}_{2} \mathrm{O}$, show a pair of doublets in a typical AX spin system (Table 1 and Figure S1, Supplementary Information (SI) section), indicating the magnetic non-equivalence of the two phosphorus atoms from the diphosphines. 


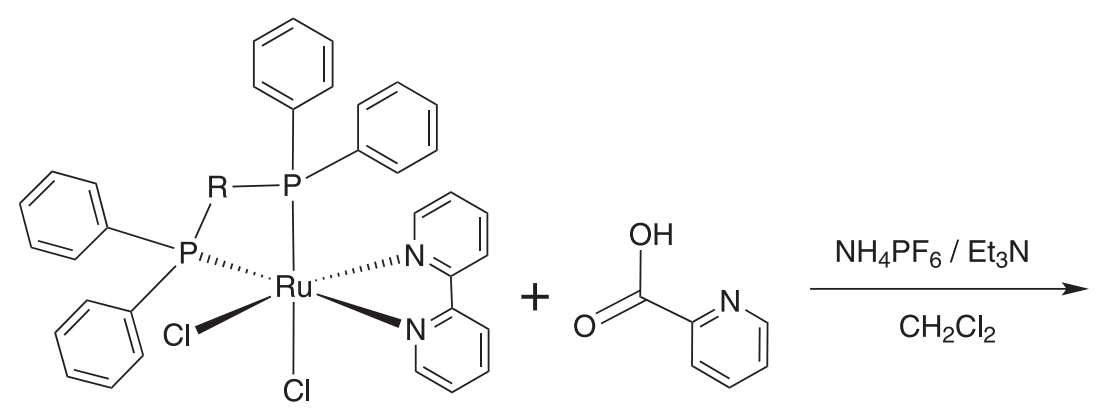<smiles></smiles>

$\begin{array}{ll}\text { (1) } \mathrm{R}=\mathrm{CH}_{2} & \text { (2) } \mathrm{R}=\mathrm{CH}_{2} \mathrm{CH}_{2}\end{array}$

(3) $\mathrm{R}=\mathrm{CH}_{2} \mathrm{CH}_{2} \mathrm{CH}_{2}$ (4) $R=$ $=0 \mathrm{Fe}$

Scheme 1. Route for synthesis of the complexes 1-4.

Table 1. ${ }^{31} \mathrm{P}\left\{{ }^{1} \mathrm{H}\right\}$ NMR $\left(161.98 \mathrm{MHz}, \mathrm{CH}_{2} \mathrm{Cl}_{2} / \mathrm{D}_{2} \mathrm{O}\right)$, electrochemical data and HOMO's energy of the compounds

\begin{tabular}{|c|c|c|c|c|}
\hline Complex & $\delta{ }^{31} \mathrm{P}\left\{{ }^{1} \mathrm{H}\right\} / \mathrm{ppm}\left({ }^{2} J_{\mathrm{PP}} / \mathrm{Hz}\right)$ & $\mathrm{E}_{\mathrm{pa}} / \mathrm{mV}$ & $\mathrm{I}_{\mathrm{pa}} / \mathrm{I}_{\mathrm{pc}}$ & $\mathrm{E}_{\text {номо }} /\left(\mathrm{kJ} \mathrm{mol}^{-1}\right)$ \\
\hline 1 & $14.9 ; 11.9(60.3)$ & 1277 & 0.99 & -762.00 \\
\hline 2 & $67.6 ; 65.1(19.0)$ & 1321 & 1.01 & -765.04 \\
\hline 3 & $35.1 ; 30.8(46.9)$ & 1206 & 0.92 & -761.89 \\
\hline 4 & $44.5 ; 37.8(32.9)$ & $822^{\mathrm{a}} / 1550$ & $0.89^{\mathrm{a}}$ & -754.33 \\
\hline cis-[RuCl${ }_{2}(\mathrm{dppm})($ bipy $\left.)\right]$ & $18.5 ; 11.2(64.3)$ & 680 & 1.06 & -442.05 \\
\hline $\operatorname{cis}-\left[\mathrm{RuCl}_{2}(\mathrm{dppe})(\mathrm{bipy})\right]$ & $68.0 ; 61.0(54.0)$ & 726 & 0.98 & -456.84 \\
\hline cis-[ $\mathrm{RuCl}_{2}(\mathrm{dppp})($ bipy $\left.)\right]$ & $37.7 ; 29.8(42.1)$ & 690 & 0.92 & -453.19 \\
\hline cis-[ $\left[\mathrm{RuCl}_{2}(\mathrm{dppf})(\mathrm{bipy})\right]$ & $41.8 ; 36.2$ & $695 / 1032^{\mathrm{a}}$ & $1.35 / 0.99^{\mathrm{a}}$ & -456.42 \\
\hline
\end{tabular}

${ }^{\mathrm{a}}$ Refers to $\mathrm{Fe} \mathrm{II}^{\mathrm{II}} / \mathrm{Fe}^{\mathrm{III}}$ couple. $\delta$ : chemical shift; ${ }^{2} J_{\mathrm{P}-\mathrm{P}}$ : P-P coupling constant; $\mathrm{E}_{\mathrm{pa}}$ : anodic peak potential; $\mathrm{I}_{\mathrm{pa}} / \mathrm{I}_{\mathrm{pc}}$ : anodic peak current/cathodic peak current ratio; dppm: bis(diphenylphosphino)methane; bipy: bipyridine; dppe: 1,2-bis(diphenylphosphino)ethane; dppp: 1,3-bis(diphenylphosphino)propane; dppf: 1,1'-bis(diphenylphosphino)ferrocene; HOMO: highest occupied molecular orbital.

\section{${ }^{31} \mathrm{P}\left\{{ }^{1} \mathrm{H}\right\}$ and ${ }^{1} \mathrm{H}$ NMR studies}

All complexes present heptets at $-144 \mathrm{ppm}$, corresponding to the $\mathrm{PF}_{6}{ }^{-}$counter-ion. The free ligands dppm, dppp, dppf and dppe show ${ }^{31} \mathrm{P}\left\{{ }^{1} \mathrm{H}\right\}$ chemical shift at $-22.0,-17.7,-16.5$ and $-11.7 \mathrm{ppm}$, respectively. Previously, we assigned the doublet in a higher frequency region to the phosphorus atoms with shorter $\mathrm{Ru}-\mathrm{P}$ distances. ${ }^{35,36}$ This assignment could be further reinforced in the kinetics studies on the coordination of benzonitrile to cis- $\left[\mathrm{RuCl}_{2}(\mathrm{dppb})(\mathrm{phen})\right]$ followed by the ${ }^{31} \mathrm{P}\left\{{ }^{1} \mathrm{H}\right\} \mathrm{NMR}$ experiment reported elsewhere. ${ }^{37}$

Interestingly, the chemical shift of the complex containing the dppe ligand is very high in comparison to the values observed for the other compounds. This can be explained in terms of the "ring contribution", 38 which is mentioned as the factor responsible for the high values of chemical shifts observed and are caused by the unshielded associated to the formation of the very stable five-membered ring. ${ }^{39}$ The stability of the complexes in the biological medium was checked by ${ }^{31} \mathrm{P}\left\{{ }^{1} \mathrm{H}\right\}$ NMR experiments, and the complexes showed to be stable in this solution for at least three days.

Concerning the ${ }^{1} \mathrm{H}$ NMR spectra of complexes 1-4, signals at 8.16-6.38 ppm correspond to twenty hydrogen atoms of the phenyl groups of the diphosphine ligands occur as a series of multiplets, while the eight protons of the bipy ligand can be observed in the typical region, in the range of 9.43-6.77 ppm. The coordination of the picolinate ligand is verified by the presence of four signals, corresponding to the four hydrogen atoms, in the region of 8.02-6.90 ppm. In complex 4, due to the non-equivalence of the phosphorus atoms and the conformation of the cyclopentadienyl $(\mathrm{Cp})$ rings, an asymmetric distribution of electronic density 
occurs and the spectrum of this compound shows signals in the 5.24-4.16 ppm region corresponding to the eight protons of $\mathrm{Cp}$ rings. The protons of the $-\mathrm{CH}_{2}-$ groups of the diphosphines are observed as multiplets in 3.20-1.87 ppm (six hydrogen atoms), 3.32-1.98 ppm (four hydrogen atoms) and 5.40-4.90 ppm (two hydrogen atoms) regions for compounds 3, 2 and 1, respectively (see Figure S2, SI section).

\section{Structural studies}

As expected, all four complexes presented distorted octahedral coordination geometry around the ruthenium center. The crystal structures of complexes 1-4 were determined (Figure 1) and the selected bond distances and angles are presented in Table 2. Data collection and experimental details are summarized in Table S1 (see SI section). The coordination of 2-picolinate to the ruthenium center formed a five-member ring with $\mathrm{N} 1-\mathrm{Ru}-\mathrm{O} 1$ angle values close to those ones found $\mathrm{N} 2-\mathrm{Ru}-\mathrm{N} 3$ bipyridine chelate ring, presenting angle values around $78^{\circ}$ for all the complexes. The bite angle measured based on $\mathrm{P} 1-\mathrm{Ru}-\mathrm{P} 2$ bond angles are 71.63(14), 82.64(3), 92.43(3) and 97.19(3) for the complexes containing the diphosphines dppm (1), dppe (2) and dppp (3) and dppf (4), respectively. Calculations showed $\mathrm{N} 2-\mathrm{Ru}-\mathrm{N} 3$ around $77^{\circ}$, for all four complexes and P1-Ru-P2 equal to 72.82, 83.90, 91.24 and $97.50^{\circ}$ for $\mathbf{1}, \mathbf{2}, \mathbf{3}$ and $\mathbf{4}$, respectively.

The structures of $\mathbf{2}$ and $\mathbf{4}$ have one molecule of water, each, in their asymmetric unities, which make hydrogen

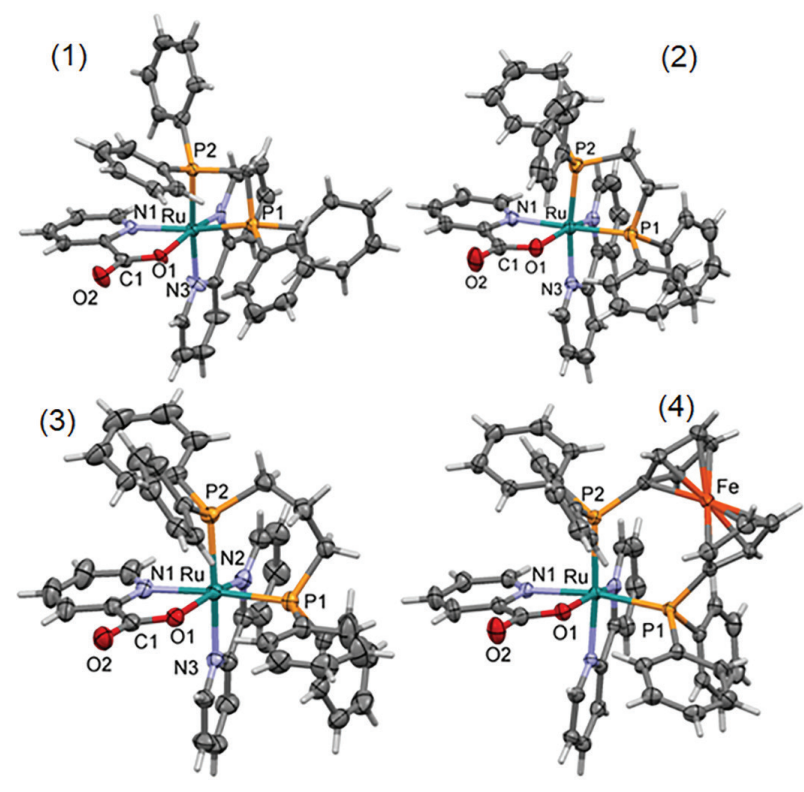

Figure 1. Crystal structure of the complexes 1, 2, 3 and $\mathbf{4}$ showing selected atoms labeling and the ellipsoids at $30 \%$ probability. $\mathrm{PF}_{6}{ }^{-}$counter-ion was omitted for clarity.
Table 2. Selected bond distances and bond angles of complexes 1-4

\begin{tabular}{lcccc}
\hline \multirow{2}{*}{ Fragment } & \multicolumn{4}{c}{ Bond distance / } \\
\cline { 2 - 5 } & $\mathbf{1}$ & $\mathbf{2}$ & $\mathbf{3}$ & $\mathbf{4}$ \\
\hline $\mathrm{Ru}-\mathrm{P} 1$ & $2.285(4)$ & $2.2998(9)$ & $2.3149(8)$ & $2.3480(7)$ \\
$\mathrm{Ru}-\mathrm{P} 2$ & $2.302(4)$ & $2.3166(9)$ & $2.3270(8)$ & $2.3515(7)$ \\
$\mathrm{Ru}-\mathrm{N} 1$ & $2.129(11)$ & $2.131(3)$ & $2.132(2)$ & $2.118(2)$ \\
$\mathrm{Ru}-\mathrm{N} 2$ & $2.108(12)$ & $2.111(3)$ & $2.105(2)$ & $2.106(2)$ \\
$\mathrm{Ru}-\mathrm{N} 3$ & $2.056(12)$ & $2.073(3)$ & $2.076(2)$ & $2.062(2)$ \\
$\mathrm{Ru}-\mathrm{O} 1$ & $2.094(9)$ & $2.087(2)$ & $2.106(2)$ & $2.094(2)$ \\
$\mathrm{C} 1-\mathrm{O} 1$ & $1.272(17)$ & $1.291(4)$ & $1.275(4)$ & $1.260(4)$ \\
$\mathrm{C} 1=\mathrm{O} 2$ & $1.219(18)$ & $1.226(5)$ & $1.223(4)$ & $1.233(4)$ \\
\hline & \multicolumn{5}{c}{ Bond angle / degree } \\
\hline $\mathrm{P} 1-\mathrm{Ru}-\mathrm{P} 2$ & $71.63(14)$ & $82.64(3)$ & $92.43(3)$ & $97.19(3)$ \\
$\mathrm{N} 2-\mathrm{Ru}-\mathrm{N} 3$ & $77.1(5)$ & $77.98(11)$ & $78.32(10)$ & $78.19(9)$ \\
$\mathrm{N} 1-\mathrm{Ru}-\mathrm{O} 1$ & $77.6(4)$ & $77.58(11)$ & $77.74(9)$ & $77.73(8)$ \\
\hline
\end{tabular}

bonds with the fluorine atoms from the $\mathrm{PF}_{6}{ }^{-}$anion and with the oxygen from picolinate ligand. The distances $\mathrm{H} \cdots \mathrm{F}$ are equal to 2.541 and $2.620 \AA$, and $\mathrm{H}$... O equal to 2.037 and $1.909 \AA$ in the complexes 2 and $\mathbf{4}$, respectively. The non-existence of individual bonds between the metal and the $\mathrm{Cp}$ rings, gives some mobility to the rings, allowing them to rotate with respect to each other. ${ }^{40}$ As a result of the coordination of the diphosphine to the ruthenium metal in a bidentate way, as well as the relatively high "bite angle" of dppf and the difference in the Ru-P bond lengths, the Cp rings are not parallel to each other. In fact, they form an angle of $2.36^{\circ}$ and present torsion angles $\mathrm{P}-\mathrm{Cp}---\mathrm{Cp}-\mathrm{P}$ of $22.99^{\circ}$ in complex 4 , which is very similar to the $c i s-\left[\mathrm{RuCl}_{2}(\mathrm{dppf})(\mathrm{bipy})\right]$ that presents a torsion angle of $19.70^{\circ},{ }^{34}$ including them in a "synclinical staggered" conformation, such as previously discussed by Bandoli and Dolmella. ${ }^{41}$

As expected, the $\mathrm{C}-\mathrm{O}$ (coordinated to ruthenium) bond lengths (ca. $1.30 \AA$ ) are longer than the $\mathrm{C}=\mathrm{O}$ distances. In the molecule of the free picolinic acid, the $\mathrm{C}=\mathrm{O}$ and $\mathrm{C}-\mathrm{OH}$ distances are equal to 1.214 and $1.278 \AA$, respectively. ${ }^{42}$ The Ru-N1distances do not change considerably with the exchange of the diphosphines, as can be seen in Table 2.

The distances of $\mathrm{Ru}-\mathrm{P}$ and $\mathrm{Ru}-\mathrm{N}_{\text {bipy }}$ bonds in the new complexes (Table 2) are shorter than in precursor complexes, indicating a more efficient back-donation from ruthenium to phosphorus atoms in the precursor complexes. In the $c i s$ - $\left[\mathrm{RuCl}_{2}\right.$ (dppe)(bipy)] complex, the $\mathrm{Ru}-\mathrm{P}$ distance is equal to 2.2465(8) $\AA$ for the phosphorus atoms trans positioned to the chlorido ligand and 2.2907(9) $\AA$ for the phosphorus atoms trans positioned to the nitrogen atom from the bipy ligand, ${ }^{35}$ while in $\mathbf{2}$ these distances are equal to 2.2998(9) $\AA$ for $\mathrm{Ru}-\mathrm{P} 1$ and 2.3166(9) $\AA$ for $\mathrm{Ru}-\mathrm{P} 2$. 
As it can be seen in Table 2, $\mathrm{Ru}-\mathrm{P}$ back donation is more efficient in the precursors complexes, because the strong electron $\sigma$ - and $\pi$ - donor character of the chlorido ligand enrich the ruthenium center of electron density, facilitating the $\mathrm{Ru}-\mathrm{P}$ backdonation. The distances $\mathrm{Ru}-\mathrm{P}$ and $\mathrm{Ru}-\mathrm{N}_{\text {bipy }}$ are in the range usually reported in the literature for complexes containing diphosphines. ${ }^{36,37}$ The packing effect must be considered because experimental measurements are made in solid state and also counter ion and solvent presence help contracting distances. These factors alter intermolecular dispersive and electrostatic forces creating a potential energy around molecules influencing their geometry. 43

\section{Electrochemical, infrared and UV-Vis studies for 1-4}

Cyclic voltammograms of compounds 1, 2 and 3 show one reversible process, with $\mathrm{E}_{\mathrm{pa}}$ (anodic peak potential) equal to 1277,1321 and $1206 \mathrm{mV}$, respectively (Table 1 and Figures S3-S6, SI section), while the precursor complexes present $\mathrm{E}_{\mathrm{pa}}$ values, around 680,726 and $690 \mathrm{mV}$, for the compounds cis-[RuCl$\left.{ }_{2}(\mathrm{dppm})(\mathrm{bipy})\right], c i s-\left[\mathrm{RuCl}_{2}\right.$ (dppe)(bipy)] and cis-[ $\mathrm{RuCl}_{2}$ (dppp)(bipy)], respectively. Complex 4 presents one quasi-reversible process with $\mathrm{E}_{\mathrm{pa}}$ equal to $822 \mathrm{mV}$, attributed to the $\mathrm{Fe}^{\mathrm{II}} / \mathrm{Fe}^{\mathrm{III}}$ redox pair and one irreversible process with $\mathrm{E}_{\mathrm{pa}}$ equal to $1550 \mathrm{mV}$ corresponding to the $\mathrm{Ru}^{\mathrm{II}} / \mathrm{Ru}^{\mathrm{III}}$ pair. Similarly, its precursor $c i s-\left[\mathrm{RuCl}_{2}(\mathrm{dppf})(\mathrm{bipy})\right]$ presents two reversible redox pairs with $\mathrm{E}_{\mathrm{pa}}$ values equals to 685 and $1032 \mathrm{mV}$, but in this case the former corresponds to $\mathrm{Fe}^{\mathrm{II}} / \mathrm{Fe}^{\mathrm{III}}$ and $\mathrm{Ru}^{\mathrm{II}} / \mathrm{Ru}^{\mathrm{III}}$, respectively. ${ }^{44,45}$ Electrochemical attribution of the redox pairs to the $\mathrm{Ru}^{\mathrm{II}} / \mathrm{Ru}^{\mathrm{III}}$ or $\mathrm{Fe}^{\mathrm{II}} / \mathrm{Fe}^{\mathrm{III}}$ process in the voltammogram of $\mathbf{4}$ was made as follows: exhaustive electrolysis at an intermediate potential $(900 \mathrm{mV})$ was performed and then a few drops of a $\mathrm{NH}_{4} \mathrm{SCN}$ solution were added to the electrochemical cell, and immediately a characteristic red color appears indicating the formation of $\left[\mathrm{Fe}(\mathrm{SCN})_{6}\right]^{3-}$, which confirms the presence of $\mathrm{Fe}^{\mathrm{III}}$. Due to the coordination of the picolinate ligand to the metal center, the $\mathrm{E}_{\mathrm{pa}}$ values increase making complexes 1-4 more stable than $c i s-\left[\mathrm{RuCl}_{2}(\mathrm{P}-\mathrm{P})(\right.$ bipy)$\left.)\right]$. This behavior can be explained because picolinate is a better $\sigma$-donor and $\pi$-acceptor ligand than the chlorido ligands, which acts as $\sigma$ - and $\pi$-donor. When the $\pi$-acceptor character of the ligand decreases, it is expected that the value of $E_{p a}$ also decreases, such as observed for the complexes $\left[\mathrm{Ru}(\text { bipy })_{3}\right]^{2+}\left(\mathrm{E}_{\mathrm{pa}}=1300 \mathrm{mV}\right),{ }^{46}$ $\left[\mathrm{Ru}(\text { pic })(\text { bipy })_{2}\right]^{+}\left(\mathrm{E}_{\mathrm{pa}}=750 \mathrm{mV}\right),{ }^{47}\left[\mathrm{Ru}(\text { pic })_{2}(\right.$ bipy $\left.)\right]$ $\left(\mathrm{E}_{\mathrm{pa}}=440 \mathrm{mV}\right)$ and $\left[\mathrm{Ru}(\mathrm{pic})_{3}\right]\left(\mathrm{E}_{\mathrm{pa}}=-90 \mathrm{mV}\right) .{ }^{48}$ From these data, it can be concluded that the $\pi$-acceptor character of the picolinate ligand is weaker than that of the bipy ligand.
In addition, the diphosphines are better $\pi$-acceptor than bipy, according to the oxidation potentials observed for the complexes synthesized herein and $\left[\mathrm{Ru}(\text { pic)(bipy) })_{2}\right] \mathrm{ClO}_{4}\left(\mathrm{E}_{\mathrm{pa}}=750 \mathrm{mV}\right)$. The substitution of one bipy in $\left[\mathrm{Ru}(\text { pic)(bipy) }]_{2}\right]^{+}$by diphosphines yielded the complexes studied here and resulted in higher $\mathrm{E}_{\mathrm{pa}}$ values of 1277, 1321, 1206 and $1550 \mathrm{mV}$ for $\mathbf{1 , 2}, \mathbf{3}$ and 4, respectively (see Table 1). ${ }^{46}$ Theoretical results support these experimental data, in which the replacement of the two chlorido atoms by the picolinate anion stabilizes the complexes. As it is well known, oxidation potential can be related to ionization potential $\left(\mathrm{E}^{\mathrm{o}} \alpha \mathrm{E}_{\mathrm{i}}\right)^{49,50}$ since both refer to the withdraw of electrons, which in turn can be associated to the highest occupied molecular orbital (HOMO) energy $\left(\mathrm{E}_{\mathrm{i}} \alpha-\mathrm{E}_{\mathrm{HOMO}}\right) .{ }^{51}$ Therefore, oxidation potential can be related to the HOMO energy, ${ }^{52}$ i.e., the lower the HOMO energy, the higher the oxidation potential. As it can be seen in Table 1, replacement of the chloride atoms from the precursor complexes $\left(\mathrm{E}_{\mathrm{Hомо}}\right.$ around $-450 \mathrm{~kJ} \mathrm{~mol}^{-1}$ ) decreases the HOMO energies in 1, 2, 3 and $4\left(\mathrm{E}_{\mathrm{HOMO}}\right.$ around $\left.-760 \mathrm{~kJ} \mathrm{~mol}^{-1}\right)$, consequently the oxidation potentials of the complexes increase.

Charge decomposition analysis (CDA) revealed that charge transference from chlorido ligands to the ruthenium atom is greater in the precursor complexes than in $\mathbf{1 - 4}$ (Table S2, SI section). For the $c i s-\left[\mathrm{RuCl}_{2}(\mathrm{dppm})(\mathrm{bipy})\right]$ complex, for instance, both chlorido atoms together donate $1.427 \mathrm{e}$ - to the metal center, but the picolinate in the complex 1 donates only $0.695 \mathrm{e}$-, which makes the ruthenium center charge more negative in the precursor complexes and explains its lower oxidation potential observed. HOMO energies are located mainly on ruthenium atoms $(60 \%)$ and chlorido ligands $(35 \%)$ in cis-[RuCl $\mathrm{R}_{2}(\mathrm{P}-\mathrm{P})($ bipy)], while after the coordination of picolinate anion to the metal center the HOMO is mostly concentrated on ruthenium atoms and on the oxygen atoms. In complexes $\mathbf{1}, \mathbf{2}$ and $\mathbf{3}$, contributions of "d" orbitals of the ruthenium to HOMO is around $70 \%$ and "p" orbitals of oxygen atoms are around $20 \%$. In 4, HOMO has $42 \%$ contribution of "d" orbitals of the ruthenium and $35 \%$ of "d" orbitals of iron (Figure 2) in its precursor. On the other hand, $59 \%$ of HOMO comprises ruthenium " $\mathrm{d}$ " orbitals and iron orbitals have a negligible participation in it. That was expected, since the first oxidation potential refers to the $\mathrm{Ru}^{\mathrm{II}} / \mathrm{Ru}^{\mathrm{III}}$ process in $c i s$ - $\left[\mathrm{RuCl}_{2}(\mathrm{dppf})(\right.$ bipy)] and to $\mathrm{Fe}^{\mathrm{II}} / \mathrm{Fe}^{\mathrm{III}}$ in 4.

In the infrared spectra the calculated and experimental vibrational data are compared. All complexes presented the expected bands relative to $v_{\text {as }} \mathrm{C}-\mathrm{H}$ and $v_{\mathrm{s}} \mathrm{C}-\mathrm{H}$ of $-\mathrm{CH}_{2}$, picolinate, bipy and phenyl moieties at around $3060-2900 \mathrm{~cm}^{-1}$ region. For complex 4, bands attributed 


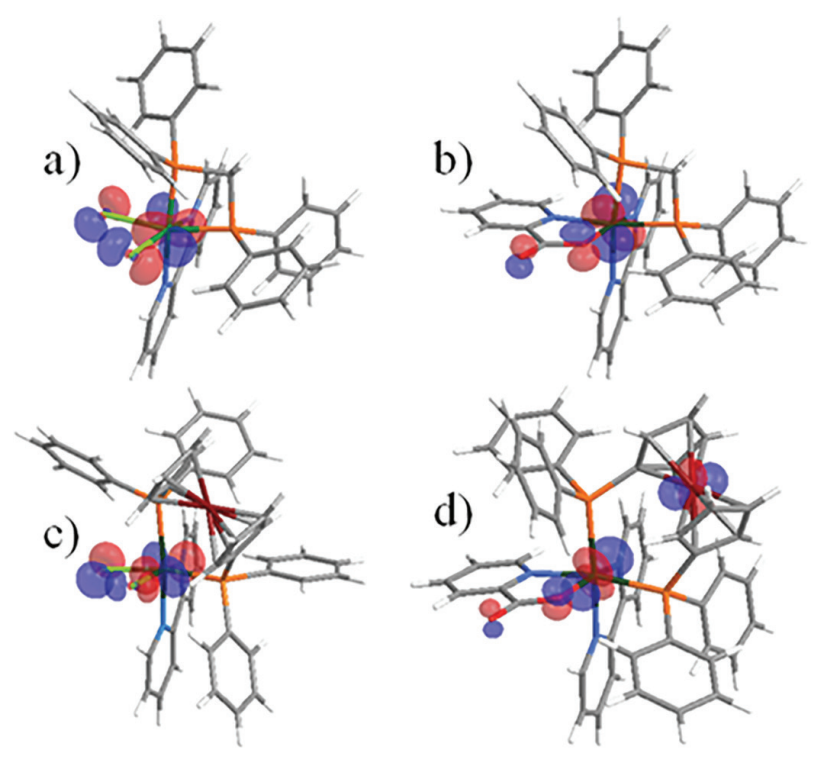

Figure 2. HOMO energies of (a) cis-[ $\left[\mathrm{RuCl}_{2}(\mathrm{dppm})(\mathrm{bipy})\right]$; (b) complex $\mathbf{1}$; (c) $c i s-\left[\mathrm{RuCl}_{2}(\mathrm{dppf})(\mathrm{bipy})\right]$ and (d) complex 4 .

to $v_{\mathrm{as}} \mathrm{C}-\mathrm{H}$ and $v_{\mathrm{s}} \mathrm{C}-\mathrm{H}$ of $\mathrm{Cp}$ rings were observed in the same region, instead of $-\mathrm{CH}_{2}$. The bands at around $1610-1400 \mathrm{~cm}^{-1}$ region were attributed to $\mathrm{C}=\mathrm{C}$ stretching. Additional bands were observed in $1400-990 \mathrm{~cm}^{-1}$ and 990-600 $\mathrm{cm}^{-1}$ regions, the former corresponding to $\mathrm{C}-\mathrm{H}$ stretching in the plane and the latter out of the plane. Bands at 840 and $557 \mathrm{~cm}^{-1}$ revealed the presence of the counterion $\mathrm{PF}_{6}{ }^{-}$. In complexes 1-4, the bands corresponding to $v_{\text {as }}(\mathrm{COO})$ and $v_{\mathrm{s}}(\mathrm{COO})$ appeared at ca. 1655 and $1335 \mathrm{~cm}^{-1}$, respectively, whereas in the free ligand these bands can be found at 1654 and $1350 \mathrm{~cm}^{-1}$, respectively. The difference between $v_{\text {as }}\left(\mathrm{COO}^{-}\right)$and $v_{\mathrm{s}}\left(\mathrm{COO}^{-}\right)$coordinated to the metal centers is an indicative of the type of coordination. In this case $v_{\text {as }}\left(\mathrm{COO}^{-}\right)-v_{\mathrm{s}}\left(\mathrm{COO}^{-}\right)$ca. $320 \mathrm{~cm}^{-1}$, it shows that the carboxylate group is coordinated to ruthenium in a monodentate way. ${ }^{53}$ Also, bands at $1600 \mathrm{~cm}^{-1}$ relative to $v(\mathrm{C}=\mathrm{N})$ were observed. For complex $\mathbf{4}$, weak bands corresponding to $v(\mathrm{Fe}-\mathrm{Cp})$ and angular deformation of $\mathrm{C}-\mathrm{H}$ bond of the cyclopentadienyl ring were observed at 546 and $1041 \mathrm{~cm}^{-1}$, respectively. For the complexes containing the diphosphines dppp, dppe and dppm weak bands corresponding to $v\left(\mathrm{P}-\mathrm{CH}_{2}\right)$ at 667,676 and $669 \mathrm{~cm}^{-1}$ were observed, respectively. The infrared (IR) spectra and their assignments for complexes 1-4 are shown in the SI section (Table S3 and Figure S7).

The UV-Vis spectra of compounds $\mathbf{1 - 4}$ are quite similar to each other (Figure S8 and Table S4, SI section). All complexes presented bands at 300 and $420 \mathrm{~nm}$ and shoulders around 340 and $500 \mathrm{~nm}$. The bands in the UV region, centered at $300 \mathrm{~nm}$ are attributed to $\pi \rightarrow \pi^{*}$ intraligand charge transference type, which is also observed in the spectra of the free ligands P-P and picH. ${ }^{21}$ Calculations support the attributions of the transitions. The bands in the region 340 (shoulder), 420 and 500 (shoulder) nm can be assigned to a metal to ligand charge transfer (MLCT). ${ }^{54}$

Cytotoxicity of 1-4 against MDA-MB-231 and murine ascistic sarcoma 180 tumor cells

Evaluation of the cytotoxicity for the complexes 1-4 against MDA-MB-231 (human breast carcinoma) and S180 (murine ascistic sarcoma 180) tumor cells, after incubation of $24 \mathrm{~h}$, were carried out. The $\mathrm{IC}_{50}$ values were calculated using the dose-survival curves with MTT (3-(4,5-dimethylthiazol-2-yl)-2,5-diphenyltetrazolium bromide) assay. Complexes 1-4 present very good activity against the MDA-MB-231 cell line (Table 3), with values of $\mathrm{IC}_{50}$ lower than cisplatin indicating their potentiality as antitumor agents. The complexes were also active against murine sarcoma, presenting $\mathrm{IC}_{50}$ values lower than $72 \mu \mathrm{M}$, while for cisplatin the $\mathrm{IC}_{50}$ value against the $\mathrm{S} 180$ cell line is $64.83 \pm 0.17 \mu \mathrm{M} .{ }^{24}$ For complexes $\mathbf{1}, \mathbf{2}, \mathbf{3}$ and $\mathbf{4}$, the $\mathrm{IC}_{50}$ values against $\mathrm{S} 180$ are equal to $71.9,31.3,11.2$ and $3.5 \mu \mathrm{M}$, respectively. Meanwhile the $\mathrm{P}-\mathrm{Ru}-\mathrm{P}$ bite angles are 71.63(14), 82.64(3), 92.43(3), 97.19(3) ̊. It is worth mentioning that the $\mathrm{IC}_{50}$ values decrease concomitantly with the diphosphine bite angle increase. This aspect suggests a relationship between these parameters. The same tendency is also observed against MDA-MB-231 tumor cells (see Table 3).

Table 3. $\mathrm{IC}_{50}$ values for complexes 1-4, against MDA-MB-231 and S180 tumor cells

\begin{tabular}{lcc}
\hline \multirow{2}{*}{ Complex } & \multicolumn{2}{c}{$\mathrm{IC}_{50}$ values / $\mu \mathrm{M}$} \\
\cline { 2 - 3 } & $\mathrm{S} 180$ & $\mathrm{MDA}-\mathrm{MB}-231$ \\
\hline $\mathbf{1}$ & $71.91 \pm 0.13$ & $14.60 \pm 4.47$ \\
$\mathbf{3}$ & $31.32 \pm 0.19$ & $7.61 \pm 0.11$ \\
$\mathbf{4}$ & $11.21 \pm 0.15$ & $3.32 \pm 0.21$ \\
Cisplatin & $3.53 \pm 0.21$ & $0.41 \pm 0.12$ \\
\hline
\end{tabular}

$\mathrm{IC}_{50}$ : drug concentration at which $50 \%$ of the cells are viable relative to the control.

Lipophilicity or partition coefficient is usually expressed by $\log \mathrm{P}$, which describes the equilibrium between water and an immiscible lipid-like organic solvent, for example $n$-octanol. $\log \mathrm{P}$ is the ratio of concentrations in the two phases $\left[\log \mathrm{P}=[\text { metallodrug }]_{(\text {in octanol) }} /[\text { metallodrug }]_{(\text {in water })}\right]$, so that a positive value for $\log \mathrm{P}$ reflects a preference for the lipid phase, and a negative value reflects the relative affinity of the complex for water. Complexes 1-4 showed 
$\log$ P positive, suggesting a preference for the lipid phase and possibly allowing permeation across biological membranes. The calculated $\log P$ showed positive values for complexes 1 $(0.95 \pm 0.15)$ and $\mathbf{2}(1.22 \pm 0.11)$, complex $\mathbf{3}(1.31 \pm 0.12)$, and complex $4(1.54 \pm 0.11)$. The order of hydrophobicity in nature of the complexes is $\mathbf{1}<\mathbf{2}<\mathbf{3}<\mathbf{4}$. Hydrophobicity is one of the most important properties to express the biological activity of the compounds, since it is necessary to cross biological membranes in order to reach their respective sites of action. Hydrophobic compounds can increase cell uptake and improve their anticancer activity.

The new compounds showed better activity than the precursor ones, except for compound 1, suggesting that the presence of picolinate ligand might play an important role in the activity of the complexes. Interestingly, the free ligands, including the picolinic acid, are not active against the tumor cells tested herein, in which the $\mathrm{IC}_{50}$ values are higher than $200 \mu \mathrm{M}$. It is important to point out that the precursor complexes $\left[\mathrm{RuCl}_{2}(\mathrm{P}-\mathrm{P})(\right.$ bipy)$\left.)\right]$ may act as pro-drugs, given that after their dissolution in DMSO, to prepare stock solution, there is a rapid exchange of one chloride ligand, reacting with DMSO.$^{55}$ A number of complexes reported in the literature ${ }^{56}$ have their antitumor activity associated to a dissociation of chloride ligand, suggesting that the mechanism possibly involves covalent interactions with DNA, which probably does not occur with the stable hexacoordinated compounds, presenting three bidentate ligands (bipy, pic, P-P) reported herein. It is worth mentioning that the complexes 1-4 are stable in DMSO solutions for at least 5 days, which was showed by ${ }^{31} \mathrm{P}$ NMR experiments. Instead, a possible mechanism to explain the activity might be a non-covalent interaction of ruthenium compounds with the DNA. ${ }^{56,57}$ Moreover, it is important to point out that DNA is not the only target aimed for antitumor agents. ${ }^{57,58}$ Further investigations are necessary to indicate the factors that are responsible for the activity of the complexes and to show the mechanism of those complexes have been conducted, since they show promising activity against the human tumor cell line with low values of $\mathrm{IC}_{50}$.

\section{Conclusions}

In this work, fournew complexes [Ru(pic)(P-P)(bipy) $] \mathrm{PF}_{6}$, pic $=$ picolinate, $\mathrm{P}-\mathrm{P}=\mathrm{dppf}$, dppp, dppe and dppm were synthesized, characterized by spectroscopic, electrochemical and X-ray crystallography techniques and had their structures elucidated theoretically. X-ray data showed that the phosphorus atoms from the diphosphine are trans positioned to the nitrogen atoms from the bipy and pic ligands. The compounds had their cytotoxicity evaluated in vitro against the human tumor cell lines MDA-MB-231 and murine ascistic sarcoma 180 showing good activities. Among the new compounds, the $\left[\mathrm{Ru}(\right.$ pic)(dppf)(bipy) $] \mathrm{PF}_{6}$ presented the highest activity against both cells tested, followed by $\left[\mathrm{Ru}(\right.$ pic)(dppp)(bipy) $] \mathrm{PF}_{6},\left[\mathrm{Ru}(\right.$ pic)(dppe)(bipy) $] \mathrm{PF}_{6}$ and $\left[\mathrm{Ru}\left(\right.\right.$ pic) $(\mathrm{dppm})($ bipy) $] \mathrm{PF}_{6}$, which may indicate that the complexes have the same mechanism of action against both MDA-MB-231 and S180 human tumor cell lines. Furthermore, higher activities were observed for those complexes containing diphosphines dppf and dppp than those containing dppe and dppm suggesting a relationship between bite angle and activity. The lipophilicity of the complexes influenced the antiproliferative activity of the cells. The most lipophilic complex was the most active. However, further investigations are necessary in order to help the elucidation of the mechanism of action of the complexes.

\section{Supplementary Information}

Crystallographic data (excluding structure factors) for the structures in this work were deposited in the Cambridge Crystallographic Data Centre as supplementary publication numbers for complex 1 (1912057), complex 2 (1815880), complex 3 (1815881) and complex 4 (1912056). Copies of the data can be obtained, free of charge, via www.ccdc. cam.ac.uk/conts/retrieving.html or from the Cambridge Crystallographic Data Centre, CCDC, 12 Union Road, Cambridge CB2 1EZ, UK; fax: +44 1223 336033. E-mail: deposit@ccdc.cam.ac.uk.

Supplementary information (the spectra and tables for 1-4) is available free of charge at http://jbcs.sbq.org.br as PDF file.

\section{Acknowledgments}

We would like to thank the Brazilian research agencies: CAPES, CNPq, FAPEMA, FAPEMIG and FAPESP. R. S. Correa would also like to thank CNPq for the financial support (403588/2016-2 and 308370/2017-1) and FAPEMIG (APQ-1674-18).

\section{Author Contributions}

Augusto Lima was responsible for the software; Rodrigo Correa for the investigation, writing-review and editing; Angelica Graminha for the investigation; Jaldyr Jesus Varela for the investigation and software; Alberico da Silva for the investigation and software; Javier Ellena for the investigation; Thales Eduardo Silva for the investigation; Alzir A. Batista for the conceptualization and supervision. 


\section{References}

1. Thota, S.; Rodrigues, D. A.; Crans, D. C.; Barreiro, E. J.; J. Med. Chem. 2018, 61, 5805.

2. Du, K. J.; Wang, J. Q.; Kou, J. F.; Li, G. Y.; Wang, L. L.; Chao, H.; Ji, L.-N.; Eur. J. Med. Chem. 2011, 46, 1056.

3. Shailendra, S.; Bharti, N.; Garza, M. T. G.; Cruz-Vega, D. E.; Garza, J. C.; Saleem, K.; Naqvi, F.; Azam, A.; Bioorg. Med. Chem. Lett. 2001, 11, 2675.

4. Liang, J. X.; Zhong, H. J.; Yang, G.; Vellaisamy, K.; Ma, D. L.; Leung, C. H.; J. Inorg. Biochem. 2017, 177, 276.

5. dos Santos, E. R.; Corrêa, R. S.; Pozzi, L. V.; Graminha, A. E.; Selistre-de-Araújo, H. S.; Pavan, F. R.; Batista, A. A.; Inorg. Chim. Acta 2017, 1, 463.

6. De, S.; Chaudhuri, S. R.; Panda, A.; Jadhav, G. R.; Kumar, R. S.; Manohar, P.; Ramesh, N.; Mondal, A.; Moorthy, A.; Banerjee, S.; Paira, P.; Kumar, S. K. A.; New J. Chem. 2019, 43, 3291.

7. Ruiz, M. C.; Kljun, J.; Turel, I.; Di Virgilio, A. L.; León, I. E.; Metallomics 2019, 11, 666.

8. Honorato, J.; Colina-Vegas, L.; Correa, R. S.; Guedes, A. P. M.; Miyata, M.; Pavan, F. R.; Ellena, J.; Batista, A. A.; Inorg. Chem. Front. 2019, 6, 376.

9. Ballester, F. J.; Ortega, E.; Porto, V.; Kostrhunova, H.; DavilaFerreira, N.; Bautista, D.; Brabec, V.; Domínguez, F.; Santana, M. D.; Ruiz, J.; Chem. Commun. 2019, 55, 1140.

10. Ivanović, I.; Grgurić-Šipka, S.; Gligorijević, N.; Radulović, S.; Roller, A.; Tešić, Ž. Lj.; Keppler; B. K.; J. Serb. Chem. Soc. 2011, 76, 53.

11. Gligorijević, N.; Aranđelović, S.; Filipović, L.; Jakovljević, K.; Janković, R.; Grgurić-Šipka, S.; Ivanović, I.; Radulović, S.; Tešić. Ž. L.; J. Inorg. Biochem. 2012, 108, 53.

12. Goitia, H.; Laguna, A.; Gimeno, M. C.; Inorg. Chim. Acta 2018 , $475,53$.

13. Villarreal, W.; Colina-Vegas, L.; Visbal, G.; Corona, O.; Corrêa, R. S.; Ellena, J.; Cominetti, M. R.; Batista, A. A.; Navarro, M.; Inorg. Chem. 2017, 56, 3781.

14. El-Asmy, H. A.; Butler, I. S.; Mouhri, Z. S.; Jean-Claude, B. J.; Emmam, M.; Mostafa, S. I.; Inorg. Chim. Acta 2016, 441, 20.

15. Silva, V. R.; Corrêa, R. S.; Santos, L. S.; Soares, M. B. P.; Batista, A. A.; Bezerra, D. P.; Sci. Rep. 2018, 8, 288.

16. Correa, R. S.; Bomfim, L. M.; Oliveira, K. M.; Moreira, D. R. M.; Soares, M. B. P.; Ellena, J.; Bezerra, D. P.; Batista, A. A.; J. Inorg. Biochem. 2019, 198, 110751.

17. Ortego, L.; Meireles, M.; Kasper, C.; Laguna, A.; Villacampa, M. D.; Gimeno, M. C.; J. Inorg. Biochem. 2016, 156, 133.

18. Pavan, F. R.; Poelhsitz, G. V.; Barbosa, M. I. F.; Leite, S. R. A.; Batista, A. A.; Ellena, J.; Sato, L. S.; Franzblau, S. G.; Moreno, V.; Gambino, D.; Leite, C. Q. F.; Eur. J. Med. Chem. 2011, 46, 5099.

19. Grgurić-Šipka, S.; Ivanović, I.; Rakić, G.; Todorović, N.; Gligorijević, N.; Radulović, S.; Arion, V. B.; Keppler, B. K.; Tešić, Ž. L.; Eur. J. Med. Chem. 2010, 45, 1051.
20. Lima, B. A. V.; Corrêa, R. S.; Graminha, A. E.; Kuznetsov, A.; Ellena, J.; Pavan, F. R.; Leite, C. Q. F.; Batista, A. A.; J. Braz. Chem. Soc. 2016, 27, 30.

21. Correa, R. S.; Freire, V.; Barbosa, M. I. F.; Bezerra, D. P.; Bomfim, L. M.; Moreira, D. R. M.; Soares, M. B. P.; Ellena, J.; Batista, A. A.; New J. Chem. 2018, 42, 6794.

22. Santos, E. R.; Graminha, A. E.; Schultz, M. S.; Correia, I.; Selistre-de-Araújo, H. S.; Corrêa, R. S.; Ellena, J.; Lacerda, E. P. S.; Pessoa, J. C.; Batista, A. A.; J. Inorg. Biochem. 2018, $182,48$.

23. Pagoto, T. M. P.; Sobrinho, L. L. G.; Graminha, A. E.; Guedes, A. P. M.; Carroccia, M. C.; de Oliveira, P. F.; Silveira-Lacerda, E. P.; Deflon, V. M.; Tavares, D. C.; Pivatto, M.; Batista, A. A.; Poelhsitz. G. V.; C. R. Chim. 2015, 18, 1313.

24. Lima, A. P.; Pereira, F. C.; Almeida, M. A. P.; Mello, F. M. S.; Pires, W. C.; Pinto, T. M.; Delella, F. K.; Felisbino, S. L.; Moreno, V.; Batista, A. A.; Silveira-Lacerda, E. P.; PLoS One 2014, 9, e105865.

25. Otwinowski, Z.; Minor, W. In Macromolecular Crystallography, Part A; Academic Press: New York, 1997.

26. Sheldrick, G. M.; Acta Crystallogr., Sect. C: Struct. Chem. 2015, C71, 3.

27. Coppens, P.; Leiserowitz, L.; Rabinovich, D.; Acta Crystallogr. 1965, 18, 1035.

28. Gorelsky, S. I.; AOMix: Program for Molecular Orbital Analysis; York University: Toronto, Canada, 1997. Available at http://www.sg-chem.net, accessed in January 2020.

29. Gorelsky, S. I.; Lever, A. B. P.; J. Organomet. Chem. 2001, 635, 187.

30. Gorelsky, S. I.; Ghosh, S.; Solomon, E. I.; J. Am. Chem. Soc. 2006, 128, 278.

31. Skripnikov. L.; Chemissian, version 2.000; 2011. Available at http://www.chemissian.com, accessed in January 2020.

32. Mosmann, T.; J. Immunol. Methods 1983, 65, 55.

33. Egorova, M. B.; Dobrachenkc, A. V.; Popov, A. M.; Koord. Khim. 1987, 13, 541.

34. Ma, G.; Macdonald, R.; Ferguson, M.; Cavell, R. G.; Patrick, B. O.; James, B. R.; Hu, T. Q.; Organomet. 2007, 26, 846.

35. Souza, L. C. M.; Santos, T. A.; do Prado, C. R. A.; Lima, B. A. V.; Corrêa, R. S.; Batista, A. A.; Otubo, L.; Ellena, J.; Ueno, L. T.; Dinelli, L. R.; Bogado, A. L.; RSC Adv. 2016, 6, 53130.

36. MacFarlane, K. S.; Joshi, A. M.; Rettig, S. J.; James, B. R.; Inorg. Chem. 1996, 35, 7304.

37. Valle, E. M. A.; Lima, B. A. V.; Ferreira, A. G.; do Nascimento, F. B.; Deflon, V. M.; Diógenes, I. C. N.; Abram, U.; Ellena, J.; Castellano, E. E.; Batista, A. A.; Polyhedron 2009, 28, 3473.

38. Garrou, P. E.; Inorg. Chem. 1975, 14, 1435.

39. Grim, S. O.; Briggs, W. L.; Barth, R. C.; Tolman, C. A.; Jesson, J. P.; Inorg. Chem. 1974, 13, 109.

40. Abel, W.; Long, N. J.; Orrell, K. G.; Osborne, A. G.; Sik, V.; J. Organomet. Chem. 1991, 403,195. 
41. Bandoli, G.; Dolmella, A.; Coord. Chem. Rev. 2000, 209, 161.

42. Hamazaki, H.; Hosomi, H.; Takeda, S.; Kataoka, H.; Ohba, S.; Acta Crystallogr., Sect. C: Cryst. Struct. Commun. 1998, 54, 9800049.

43. Jacobsen, H. A.; J. Chem. Theory Comput. 2011, 7, 3019.

44. Appelt, P.; da Silva, J. P.; Fuganti, O.; Aquino, L. E. N.; Sandrino, B.; Wohnrath, K.; Santos, V. A. Q.; Cunha, M. A. A.; Veiga, A.; Murakami, F. S.; Back, D.F.; de Araujo, M. P.; J. Organomet. Chem. 2017, 846, 326.

45. Gallatti, T. F.; Bogado, A. L.; Poelhsitz, G. V.; Ellena, J.; Castellano, E. E.; Batista, A. A.; Araujo, M. P.; J. Organomet. Chem. 2007, 692, 5447.

46. Tokel-Takvoryan, N. E.; Hemingway, R. E.; Bard, A. J.; J. Am. Chem. Soc. 1973, 95, 6582

47. Ghatak, N.; Chakravarty, J.; Bhattacharya, S.; Transition Met. Chem. 1995, 20, 138.

48. Ghatak, N.; Chakravarty, J.; Bhattacharya, S.; Polyhedron 1995, 14,3591

49. Basolo, F.; Pearson, R. G.; Mechanism of Inorganic Reactions, $2^{\text {nd }}$ ed.; John Wiley and Sons, Inc.: New York, 1967, p. 27 and 223.

50. Pascariu, A.; Iliescu, S.; Popa, A.; Ilia, G.; J. Organomet. Chem. 2009, 694, 3982.
51. Nelsen, S. F.; Blackstock, S. C.; Petillo, P. A.; Agmon, I.; Kaftory, M.; J. Am. Chem. Soc. 1987, 109, 5724.

52. Nelsen, S. F.; Petillo, P. A.; Frigo, T. B.; Chang, H.; Dougherty, D. A.; Kaftory, M. J.; Org. Chem. 1991, 56, 613.

53. Tsiper, E. V.; Soos, Z. G.; Gao, W.; Kahn, A.; Chem. Phys. Lett. 2002, 360, 47.

54. Sviatenko, L. K.; Gorb, L.; Hill, F. C.; Leszczynski, J.; J. Comput. Chem. 2013, 34, 1094.

55. Nakamoto, K.; Infrared and Raman Spectra of Inorganic and Coordination Compounds, $5^{\text {th }}$ ed.; Wiley-Interscience: New York, 1997.

56. Nakamoto, K.; Tsuboi, M.; Strahan, G. D.; Drug-DNA Interactions: Structures and Spectra; John Wiley \& Sons: Hoboken, New Jersey, 2008.

57. Cunha, B. N.; Colina-Vegas, L.; Plutín, A. M.; Silveira, R. G.; Honorato, J.; Oliveira, K. M.; Cominetti, M. R.; Ferreira, A. G.; Castellano, E. E.; Batista, A. A.; J. Inorg. Biochem. 2018, 186, 156.

58. Savić, A.; Marzo, T.; Scaletti, F.; Massai, L.; Bartoli, G.; Hoogenboom, R.; Messori, L.; Van Deun, R.; Van Hecke, K.; BioMetals 2019, 32, 3 .

Submitted: September 10, 2019 Published online: February 5, 2020 